\title{
ANALISIS POTENSI SPORT TOURISM DI PANTAI INDAH KEMANGI KENDAL
}

\author{
Nofarizqi Hanidar'), Maftukin Hudah²), Danang Aji Setyawan ${ }^{3)}$ \\ ${ }^{1}$ Fakultas Pendidikan Ilmu Pengetahuan Sosial dan Keolahragaan, Universitas PGRI Semarang \\ Email: fariz.nofarizq@gmail.com \\ ${ }^{2}$ Fakultas Pendidikan Ilmu Pengetahuan Sosial dan Keolahragaan, Universitas PGRI Semarang \\ Email: maftukinhudah10@gmail.com \\ ${ }^{3}$ Fakultas Pendidikan Ilmu Pengetahuan Sosial dan Keolahragaan, Universitas PGRI Semarang \\ Email: danangpjkrupgris@gmail.com
}

\begin{tabular}{l}
\hline Artikel Info \\
\hline \\
Koresponden penulis : \\
Nofarizqi Hanidar \\
Email: fariz.nofarizq@gmail.com \\
$\square$ Diterima 24 November 202 \\
$\square$ Direview 18 Januari 2022 \\
$\square$ Disetujui 29 Januari 2022 \\
$\square$ Dipublikasi 31 Januari 2022
\end{tabular}

Kata Kunci:

Sport, Tourism, Kendal

Keywords:

Keywords should i

Sport, Tourism, Kendal

\begin{abstract}
Abstrak
Tujuan penelitian ini adalah untuk menganalisis berbagai potensi pariwisata khususnya sektor pariwisata olahraga. Penelitian ini merupakan penelitian deskriptif dengan pendekatan kualitatif. Pengumpulan data menggunakan metode observasi, wawancara dan dokumentasi. Analisis data menggunakan metode yang dilakukan secara terus menerus dengan reduksi data, penyajian data dan penarik kesimpulan. Hasil penelitian ini menunjukan bahwa potensi pariwisata olahraga yang dapat dikembangkan di Pantai Indah Kemangi antara lain seperti paralayang dan speed boat. Pantai Indah Kemangi memiliki banyak jenis wisata, dengan didukungnya fasilitas yang memadai, dan harga yang ekonomis. Namun, pantai ini juga memerlukan perawatan yang lebih karena seperti kebersihan, dan beberapa fasilitas tambahan perlu ditingkatkan. Pemanfaatan media informasi untuk sarana promosi sangat perlu ditingkatkan. Berdasarkan hasil penelitian, dapat disimpulkan bahwa adanya potensi pariwisata olahraga di Pantai Indah Kemangi. Saran kepada seluruh pelaku pariwisata untuk saling bekerja sama, membangun komunikasi dengan baik dan bertanggung jawab dalam setiap tugas dan wewenang. Perlunya evaluasi dan inovasi untuk bisa melahirkan ide-ide baru yang nantinya akan direalisasikan demi perkembangan dan kemajuan Pantai Indah Kemangi.
\end{abstract}

\section{Abstract}

Aim in this study was to analyze various tourism potentials, especially the sports tourism sector. This research is a descriptive research with a qualitative approach. Collecting data using the method of observation, interviews and documentation. Data analysis uses a method that is carried out continuously with reduction.The results of this study indicate that the potential for sports tourism that can be developed at Pantai Indah Kemangi, among others, such as paragliding and speed boats. Pantai Indah Kemangi has many types of tourism, supported by adequate facilities, and at an economical price. However, this beach also requires more maintenance because such as cleanliness, and some additional facilities need to be improved. The use of information media for promotional tools really needs to be improved. Suggestions to all tourism actors to work together, build good communication and be responsible in every task and authority that has been mandated. The need for evaluation and innovation to be able to give birth to new ideas that will later be realized for the development and progress of Pantai Indah Kemangi. 


\section{Journal STAND: Sports and Development}

http://jurnal.unipasby.ac.id/index.php/stand/about/submissions jurnal.stand@unipasby.ac.id

\section{PENDAhuluan}

Sport Tourism adalah kegiatan wisata dan berolahraga. Olahraga dalam wisata bukan hanya untuk profesional saja, namun juga diperuntukan segala kalangan, mulai dari komunitas profesional hingga amatir. Pariwisata dan olahraga merupakan dua ilmu yang dapat dikombinasikan sehingga mempunyai kekuatan dan efek ganda terhadap pertumbuhan ekonomi di Indonesia. Oleh karena itu pariwisata dan olahraga (Sport Tourism).

Pantai Indah Kemangi, di Desa Jungsemi, Kecamatan Kangkung, Kendal belum lama ini telah diresmikan oleh Sekretarus Daerah (Sekda) Kabupaten Kendal, Moh Toha. Wisata pantai tersebut dikembangkan oleh Pemdes Jungsemi bersama Lembaga Penelitian dan Pengabdian Masyarakat (LPPM) Universitas PGRI Semarang (UPGRIS). Lahan perkebunan yang terkelola dengan baik bisa menjadikan ciri khas desa wisata Pantai Indah Kemangi.

Setelah diresmikannya Pantai Indah Kemangi, tidak menutup kemungkinan dapat dikembangkannya sport tourism di area tersebut. Mengingat tempat bernuansa eksotis tersebut memiliki banyak tempat dan lahan yang bisa diolah. Dilansir dari website resmi Diskominfo Provinsi Jawa Tengah, Keindahan Pantai Indah Kemangi yang berada di Kecamatan Kangkung dinilai mempunyai daya tarik dan bisa dikembangkan menjadi sport tourism. Bupati daerah setempat memiliki harapan dengan dijadikannya Pantai Indah Kemangi sebagai sport tourism akan membangkitkan UMKM warga sekitar.

\section{METODE PENELITIAN}

Penelitian ini menggunakan jenis penelitian deskriptif dengan pendekatan kualitatif. Penelitian ini berarti menjabarkan gambaran data yang telah diperoleh melalui wawancara dan observasi. Maka dari itu, pada laporan penelitian, data yang dikemukakan dan dianalisis merupakan data dalam bentuk hasil wawancara dan observasi. Pada teknik penelitian ini peneliti menggunakan pengumpulan data melalui pengamatan/observasi dan wawancara (interview) dan dokumen tambahan sebagai dokumentasi.

Subjek penelitian berupa informasi yang dijadikan fokus dalam penelitian ini berupa informasi yang didapatkan dari Dinas Pariwisata, Kepala Desa Jungsemi, pengelola wisata, masyarakat sekitar lokasi wisata, dan wisatawan. Pengumpulan data menggunakan metode observasi, wawancara dan dokumentasi. Analisis data menggunakan metode yang dilakukan secara terus menerus dengan reduksi data, penyajian data dan penarik kesimpulan.

Volume 2 Nomor 2 Tahun 2021 | 121 


\section{Journal STAND: Sports and Development}

http://jurnal.unipasby.ac.id/index.php/stand/about/submissions jurnal.stand@unipasby.ac.id

\section{HASIL DAN PEMBAHASAN}

Hasil penelitian ini menunjukan bahwa potensi pariwisata olahraga yang dapat dikembangkan di Pantai Indah Kemangi antara lain seperti paralayang dan speed boat. Pantai Indah Kemangi.memiliki banyak jenis wisata, dengan didukungnya fasilitas yang memadai, dan harga yang ekonomis. Namun, pantai ini juga memerlukan perawatan yang lebih karena seperti kebersihan, dan beberapa fasilitas tambahan perlu ditingkatkan. Pemanfaatan media informasi untuk sarana promosi sangat perlu ditingkatkan.

Jenis pariwisata yang dimiliki Pantai Indah Kemangi bisa dibilang bervariasi, diantaranya adalah pariwisata foto, pariwisata alam, pariwisata olahraga, bahkan yang barubaru ini dikembangkan adalah pariwisata edukasi. Dari banyaknya jenis pariwisata ini tentunya dapat menjadi daya tarik tersendiri untuk wisatawan yang mengunjungi Pantai Indah Kemangi.

Sarana dan prasarana yang terdapat pada obyek wisata Pantai Indah Kemangi bisa dikatakan lengkap, terawat, dan berfungsi sebagai mana mestinya. Meskipun ada beberapa sarana dan prasarana yang dirasa kurang, namun hal itu tidak terlalu berefek. Ada yang memang memiliki bangunan permanen, diantaranya adalah pintu loket, kantor sekretariat, mushola, gazebo, kamar mandi, dan warung makan. Dengan adanya bangunan tersebut, tentunya sangat menunjang kenyamanan wisatawan ketika berkunjung ke Pantai Indah Kemangi.

Meskipun dulu Pantai Indah Kemangi memiliki nuansa mistis karena tidak jauh dari jalan menuju lokasi obyek wisata ada makam yang dikeramatkan, sekarang hal itu tertutupi dengan panorama yang begitu memukai. Banyak pohon cemara laut yang ditanam, menjadikan hawa panas bisa diminimalisir. Tingkat kebersihan yang sampai saat ini berusaha untuk tetap terjaga pula yang menjadikan para wisatawan betah untuk tetap berada disini bahkan tidak akan ragu untuk datang ke Pantai Indah Kemangi dilain kesempatan.

Keamanan di obyek wisata ini dibantu oleh warga setempat, Untuk wahana yang memiliki risiko tinggi seperti halnya banana boat, jet sky dan rolling donut, diwajibkan untuk menggunakan pelampung sebagai keamanan wajib. Hal ini tentu ditujukan untuk menunjang keamanan dan keselamatan wisatawan. Ketika lingkungan tidak bersahabat juga pengelola mempertimbangkannya. Bahkan ketika hendak menaiki ATV, dari pengelola ATV menjelaskan apa yang seharusnya dan apa yang tidak seharusnya dilakukan oleh wisatawan ketika ingin mencoba mengendarai ATV demi keamanan dari wisatawan, untuk meminimalisir risiko yang nantinya terjadi. Hal ini membuktikan bahwa keamanan dan 


\begin{tabular}{c|c|}
\hline Journal STAND: Sports and Development \\
http://jurnal.unipasby.ac.id/index.php/stand/about/submissions \\
unipa Surnalaya
\end{tabular}

keselamatan wisatawan sangat dijunjung tinggi.

Harga tiket untuk dapat masuk ke dalam Pantai Indah Kemangi adalah sebesar Rp. 5.000,- atau lima ribu rupiah per wisatawan. Beberapa produk makanan dan minuman disini juga dibandrol dengan harga yang layak. Meskipun di tempat wisata lain biasanya akan menaikan harga makanan maupun minuman, tetapi tidak dengan Pantai Indah Kemangi.

Karyawan dan pengelola wisata yang ramah akan memberikan respon positif oleh pengunjung atau wisatawan. tidak menutup kemungkinan bahwa lokasi wisata Pantai Indah Kemangi akan berkembang lebih baik jika sesuatu yang positif dapat dipertahankan dengan baik. Dari pengelola hingga masyarakat sekitar mencoba untuk memberi pelayanan yang terbaik, dan ramah terhadap wisatawan. Serta wisatawan sendiri yang merasakan usaha dari pihak pengelola serta masyarakat sekitar dan hal ini tentunya perlu ditingkatkan atau paling tidak dipertahankan.

Promosi terkait keberadaan Pantai Indah Kemangi masih tergolong pasif. Promosi belum terlalu aktif dalam media sosial, dan masih mempunyai followers yang tergolong sedikit, sehingga jarang ada orang yang tahu adanya wahana bahkan tempat wisata Pantai Indah Kemangi di Kendal. Promosi dalam bentuk iklan di instagram maupun media sosial lainnya belum berjalan dengan baik, maka dari itu Pantai Indah Kemangi mempunyai kelemahan dalam promosi yang kurang efektif dan informatif. Kekurangan ini sangat berefek terhadap lokasi wisata, karena ketika bisa memaksimalkan promosi tentunya akan menunjang banyaknya wisata yang akan berkunjung, atau paling tidak akan memberi tahu bahwa destinasi wisata Pantai Indah Kemangi itu ada.

Kebersihan merupakan aspek utama yang sangat perlu untuk diertimbangkan. Karena hal itulah yang mendukung kenyamanan ketika berada di suatu tempat, terlebih tempat wisata. Dari hasil wawancara dan observasi memang kebersihan yang ada di Pantai Indah Kemangi sangat perlu untuk ditingkatkan kembali. Mengingat banyak sekali sampah yang dibuang tidak pada tempatnya. Memang banyak faktor yang mempengaruhi tingkat kebersihan itu, seperti tingkat kesadaran akan membuang sampah pada tempatnya. Kebanyakan dari wisatawan mengeluhkan hal yang sama, yaitu kebersihan akan lokasi wisata. Banyak yang memiliki harapan agar Pantai Indah Kemangi, kedepannya lebih bersih.

Pengembangan terhadap beberapa fasilitas disini mengacu kepada fasilitasfasilitas yang belum ada di area Pantai Indah Kemangi, seperti pusat perbelanjaan, transportasi umum, dan penginapan atau home stay untuk para wisatawan. Kemudian juga untuk pusat perbelanjaan, dan penginapan juga. 


\section{Journal STAND: Sports and Development}

http://jurnal.unipasby.ac.id/index.php/stand/about/submissions jurnal.stand@unipasby.ac.id

Akses menuju Pantai Indah Kemangi yang kurang begitu baik dan sempit akan menjadi hambatan yang besar jika tidak diatasi. Dari hasil observasi dan wawancara memang jalan yang dilalui merupakan jalan perkampungan yang sempit, dan akan kesulitan jika ada persimpangan antara mobil yang dating dengan mobil yang pergi maupun sebaiknya. Hal tersebut dapat mempengaruhi jumlah pengunjung yang ingin berkunjung ke Pantai Indah Kemangi karena jalan yang dilalui untuk menuju ke obyek wisata kurang begitu nyaman. Beberapa wisatawan juga sering mengeluhkan terkait kondisi akses jalan menuju lokasi.

Wisatawan yang terus meningkat setiap tahunnya terhitung sejak disahkannya Pantai Indah Kemangi, memberikan peluang tersendiri bagi pantai ini. Peningkatan wisatawan sangat mempengaruhi kondisi tempat wisata. Ketika wisatawan yang datang ke Pantai Indah Kemangi semakin meningkat, tentunya akan membantu pengembangan lokasi yang ada. Pantai Indah Kemangi merupakan destinasi wisata yang dikelola oleh BUMDes. Maka dari itu, semakin tinggi peningkatan wisatawan yang dating, semakin tinggi juga kemungkinan berkembangnya Pantai Indah Kemangi ini. Selain dapat menjadi pendapatan daerah, tentunya hal tersebut dapat menjadi lapangan pekerjaan bagi masyarakat desa.
Dengan adanya kerja sama yang baik, akan mempercepat pembangunan dan pengembangan destinasi wisata Pantai Indah Kemangi. Pantai Indah Kemangi berkembang begitu pesat sejak awal mulai pengembangan. Beberapa pihak lain yang ikut membantu pengembangan desa wisata tersebut antara lain dari Universitas PGRI Semarang dan Baznas. Dengan kondisi yang ada saat ini, tidak menutup kemungkinan bahwa Pantai Indah Kemangi masih akan terus mencoba menjalin kerjasama dengan pihak lain.

Pantai Indah Kemangi merupakan pantai yang bisa dikategorikan sebagai pantai yang baru. Meskipun demikian, banyak yang menyatakan bahwa peningkatan dalam pengembangan pantai tersebut sangatlah signifikan. Banyak wisatawan yang tertarik dengan sarana wisata yang ada di lokasi tersebut. Banyak juga wisatawan yang tidak ragu untuk mencoba wisata olahraga yang ada. Dari sini jelas sekali keinginan untuk berkembangnya wahana wisata, hal ini merupakan peluang untuk dapat memajukan tempat wisata tersebut. Beberapa wahana yang sering disinggung oleh wisatawan antara lain seperti speed boat dan paralayang.

Strategi pemasaran saat ini tidak hanya mengenai menyebarkan browsur. Seseorang yang bergerak dalam bidang pemasaran harus pintar dalam mengambil kesempatan yang ada. Saat ini teknologi informasi sudah semakin maju. Teknologi informasi saat ini sangat 
berguna bagi perusahaan untuk menjaring untuk menjaring pasar lebih luas. Sangat disayangkan ketika keindahan dan keberagaman wisata di Pantai Indah Kemangi tidak diketahui oleh banyak orang.

Dengan diberlakukannya peraturan pemerintah terkait dengan PPKM tersebut, menjadikan keleluasaan untuk mengembangkan objek wisata terhambat. Pembatasan tersebut memang menjadi ancaman yang dapat mematikan sektor pariwisata. Dengan adanya aturan baru tersebut, sangat bisa dirasakan dengan penurunan jumlah wisatawan yang datang.

$$
\text { Kepedulian wisatawan terhadap }
$$
lingkungan di Pantai Indah Kemangi terbilang masih sangat kurang, banyak dijumpai wisatawan yang tidak bertanggung jawab terhadap lingkungan yang ada. Di Pantai Indah Kemangi sendiri, sampai saat ini banyak wisatawan yang kurang sadar akan menjaga lingkungan, hal tersebut dapat menjadi ancaman besar bagi obyek wisata, mengingat kebersihan adalah hal yang sangat mempengaruhi kenyamanan ketika berada di suatu tempat wisata.

\section{KESIMPULAN}

Berdasarkan hasil penelitian, dapat disimpulkan bahwa adanya potensi pariwisata olahraga di Pantai Indah Kemangi. Saran kepada seluruh pelaku pariwisata untuk saling bekerja sama, membangun komunikasi dengan baik dan bertanggung jawab dalam setiap tugas dan wewenang yang telah diamanahkan. Perlunya evaluasi dan inovasi untuk bisa melahirkan ide-ide baru yang nantinya akan direalisasikan demi perkembangan dan kemajuan Pantai Indah Kemangi.

\section{REFERENSI}

Afrilian, P. (2018). Pengaruh Kesuksesan Penyelenggaraan Event Sport Tourism Triathlon Pariaman Dalam Meningkatkan Kunjungan Wisatawan Mancanegara Dari Tahun 2014 Sampai Tahun 2017. JURNAL STAMINA, 1(1), 12-23.

Anggito, A., \& Setiawan, J. (2018). Metodologi penelitian kualitatif. CV Jejak (Jejak Publisher).

Arikunto, S. (2013). Prosedur penelitian suatu pendekatan praktik.

Astuti, M. T. (2015). Potensi Wisata Olah Raga Dalam Meningkatkan Kunjungan Wisatawan Sport Tourism to Increase Tourist Arrival In Indonesia. Jurnal Kepariwisataan Indonesia, 10(1).

Astuti, M. T. (2015). Potensi Wisata Olah Raga Dalam Meningkatkan Kunjungan Wisatawan Sport Tourism to Increase Tourist Arrival In Indonesia. Jurnal Kepariwisataan Indonesia, 10(1).

Finahari, N., Rubiono, G., \& Qiram, I. (2019, October). Analisis Potensi Tari Gandrung Banyuwangi Sebagai Tarian Wisata Olahraga (Sport Tourism). In Prosiding 


\section{Journal STAND: Sports and Development}

http://jurnal.unipasby.ac.id/index.php/stand/about/submissions jurnal.stand@unipasby.ac.id

Seminar Nasional IPTEK Olahraga (SENALOG) (Vol. 2, No. 1).

Hudah, M. (2017, May). Sport Tourism Sebagai Strategi dan Tantangan Perkembangan Social Olahraga dalam Kehidupan Masyarakat. In Seminar Nasional KeIndonesiaan II Tahun 2017.

Kencana, P. N. (2011). Peranan Sektor

Pariwisata Dalam Perekonomian Provinsi

DKI Jakarta:Analisis Input Output. Skripsi. Fakultas Ekonomi dan Manajemen IPB. Bogor.

Larassary, A. (2020). Perspektif Pengalaman Konsumen Terhadap Kesuksesan Event Lari Borobudur Marathon 2019. JUARA:Jurnal Olahraga, 5(2), 163-174.

Mania, S. (2017). Observasi Sebagai Alat Evaluasi dalam Dunia Pendidikan dan Pengajaran. Lentera Pendidikan: Jurnal Ilmu Tarbiyah Dan Keguruan, 11(2), 220233.

Maryam, Selvia. 2011. 'Pendekatan Swot Dalam Pengembangan Objek Wisata Kampoeng Djowo Sekatul Kabupaten Kendal. Skripsi pada Universitas Ekonomi Universitas Diponegoro Semarang.

Masjhoer, J. M. (2019). Model Pengembangan International Musi Triboatton sebagai Atraksi Sport Tourism. Jurnal Pariwisata Terapan, 3(2), 154-160.
Masjhoer, J. M., Susetyarini, O., \& Vitrianto, P. N. Implementasi Sport Tourism dalam Pemanfaatan Potensi Sungai di Indonesia Studi kasus:International Musi Triboatton 2015.

Maulana, M. A. (2020). Analisis Sport Tourism Pantai Tirta Samudera di Kabupaten Jepara. JPAS:Journal of Physical Activity and Sports, 1(1), 71-79.

Moleong, L. J. (2010). Metodologi penelitian kualitatif. Bandung: Remaja Rosdakarya.

Nugrahani, F., \& Hum, M. (2014). Metode penelitian kualitatif. Solo: Cakra Books.

Octaviani, R., \& Sutriani, E. (2019). Analisis Data dan Pengecekan Keabsahan Data.

Rahardjo, M. (2011). Metode pengumpulan data penelitian kualitatif.

Rahardjo, M. (2017). Studi kasus dalam penelitian kualitatif: konsep dan prosedurnya.

Soleh, A. (2017). Strategi pengembangan potensi desa. Jurnal Sungkai, 5(1), 32-52.

Sugiyono. (2018). Metode Penelitian Kuantitatif, Kualitatif dan R\&D. Alfabeta, Bandung.

Sugiyono. (2013). Metode Penelitian Kuantitatif, Kualitatif dan R\&D. Alfabeta, Bandung.

Sugiyono. (2016). Metode Penelitian Kuantitatif, Kualitatif dan R\&D. Alfabeta, Bandung.

Volume 2 Nomor 2 Tahun 2021 | 126 


\begin{tabular}{|c|c|}
\hline Journal STAND: Sports and Development \\
http://jurnal.unipasby.ac.id/index.php/stand/about/submissions \\
jurnal.stand@unipasby.ac.id
\end{tabular}

Sugiyono. (2017). Metode Penelitian

Kuantitatif, Kualitatif dan R\&D (ke-25). ALFABETA.

Suryani, N. L. M., Noak, P. A., \& Yudhartha,

I. P. D. (2016). Analisis Manajemen

Pengelolaan Obyek Wisata Dalam

Mewujudkan Pembangunan Pariwisata

Yang Berkelanjutan Melalui Badan

Usaha Milik Desa Adat (Bumda)(Studi

Kasus Obyek Wisata Pantai Pandawa

Kuta Selatan Kabupaten Badung). Citizen

Charter, 1(1), 165229.

Tersiana, A. (2018). Metode Penelitian.

Yogyakarta: Start Up.

Undang-Undang No. 10 tahun 2009 tentang

Kepariwisataan.
Undang-undang No. 6 Tahun 2014 tentang Desa.

Wijaya, H. (2018). Analisis data kualitatif ilmu pendidikan teologi. Sekolah Tinggi Theologia Jaffray.

Zain, A. R., Hudah, M., \& Wibisana, M. I. N. (2020). Motivasi Masyarakat Dalam Aktivitas Olahraga Rekreasi Pada Event Car Free Day Di Karesidenan Pati Tahun 2020. JPAS:Journal of Physical Activity and Sports, 1(1), 53-62.

Zellatifanny, C. M., \& Mudjiyanto, B. (2018). Tipe penelitian deskripsi dalam ilmu komunikasi. Diakom: Jurnal Media Dan Komunikasi, 1(2), 83-90. 